\title{
A Vida de Sara e o Cumprimento da Promessa-Aliança: exegese narrativa de $\mathrm{Gn} 23,1-20$
}

\author{
Orientador: Leonardo Agostini Fernandes \\ Doutoranda: Elizangela Chaves Dias \\ Área de Concentração: Teologia Bíblica
}

Linha de Pesquisa: Análise e Interpretação de Textos do Antigo e Novo Testamento

O tema proposto para exegese narrativa de Gn 23,1-20 é "A Vida de Sara e o Cumprimento da Promessa-Aliança". O interesse por esse tema deriva da participação da matriarca Sara no cumprimento da promessa-aliança de filho, bênção e terra feita por Deus a Abraão (cf. Gn 11,26-25,11). No ato da escrita há uma intenção que conduz cada escolha. Desse modo, a eleição do gênero literário de "relato de morte e sepultamento" para unir conteúdos distintos como morte e aquisição de propriedade parece não ser fruto do acaso. Quanto a Gn 23,1-20, particularmente chama a atenção o fato de o referido morto ser identificado com Sara e a terra negociada ser identificada como Macpela, em Cariat Arbe ou Mambré, que é Hebron, na terra de Canaã. A leitura sistemática do último episódio narrado sobre a vida de Sara permite constatar que a aquisição do campo com a gruta de Macpela, a árvore e tudo o que está ao seu redor foi possível para Abraão graças a Sara, o que corrobora a hipótese desta tese: ao lado de Abraão, Sara é elemento essencial para o cumprimento da promessa-aliança, pois, no conjunto das promessas em que Abraão é o receptor e o destinatário, Sara está essencialmente implicada em seu cumprimento. De um lado, a compra do campo de Macpela pode ser interpretada como cumprimento da promessa-aliança do dom da terra no ciclo de Abraão e Sara e como prefiguração do cumprimento da promessa-aliança do dom de toda a terra. Do outro lado, o sepultamento de Sara, na terra de Canaã, também sugere uma prolepse da posse da terra, uma vez que sua gruta sepulcral tornou-se marca física de demarcação territorial no Hebron. Esse desfecho revela que Abraão é o primeiro ancestral imigrante do antigo Israel a possuir propriedade de terra 
em Canaã; Sara é a primeira memória ancestral a ser sepultada na terra da promessa; e a aquisição de Macpela concede o status de propriedade ancestral e inalienável (cf. 1Rs 21,3). Nessa perspectiva, Sara, a geradora da semente/ sêmen da promessa-aliança (cf. Gn 17,16.19), dá sentido teológico à gruta de Macpela, a qual mais tarde receberá Abraão e sua "descendência" (cf. Gn 17,8). Sara (cf. Gn 23,1-20), Abraão (cf. Gn 25,9), Isaac (cf. Gn 35,29), Rebeca e Lia (cf. Gn 49,31) e Jacó (cf. Gn 50,13), todos os patriarcas e matriarcas desenraizados, são "plantados" em Macpela, tornando-se os seus guardiões para sempre. Se o útero estéril de Sara é a porta de entrada de Israel na história, seu túmulo é, igualmente, a porta de entrada de Israel na posse da terra de Canaã. Ela é a primeira ancestral de Israel a ser introduzida no ventre da terra prometida, abrindo, assim, espaço para que os demais patriarcas e matriarcas da promessa com ela se reúnam.

Palavras-chave: Exegese Narrativa. Relato de Morte e Sepultamento. 